\title{
Photocatalytic pretreatment for the redox conversion of waste activated sludge to enhance biohydrogen production
}

Chunguang Liu ${ }^{a}$, Wansheng Shi ${ }^{a}$, Mijung Kim ${ }^{a}$, Yingnan Yang ${ }^{a}$, Zhongfang Lei ${ }^{a}$, Zhenya Zhang ${ }^{\text {a* }}$

${ }^{a}$ Graduate School of Life and Environmental Science, University of Tsukuba, 1-1-1 Tennodai, Tsukuba, Ibaraki 305-8572, Japan

\footnotetext{
Abstract

*Corresponding author: Zhenya Zhang. Tel/fax.: +81 298534712.

E-mail address: zhang.zhenya.fu@u.tsukuba.ac.jp (Z. Zhang).
} 
Photocatalytic pretreatment of waste activated sludge (WAS) using a flat photocatalytic reactor was undertaken. Photocatalytic pretreatment enhanced the release of soluble substances from WAS, in which the soluble protein and soluble carbohydrate concentration increased by about $50 \%$ and $80 \%$, respectively. Significant removal of heavy metal ions from the liquid phase of WAS was also achieved after photocatalytic pretreatment. In addition, the highest hydrogen yield and the highest concentration of volatile fatty acids (VFAs) were achieved from the photocatalysis pretreated WAS by batch anaerobic digestion $\left(55^{\circ} \mathrm{C}\right)$. The cumulative hydrogen yield from photocatalysis pretreated WAS was $211.0 \mathrm{ml} / \mathrm{l}$-sludge, much higher than those from UV pretreated WAS (111.0 ml/1-sludge) and from raw WAS (93.0 $\mathrm{ml} / \mathrm{l}$-sludge). The results indicate that photocatalysis is a promising WAS pretreatment method for the enhancement of biohydrogen production, probably due to the photo-oxidation of organics and simultaneous photo-reduction of heavy metal ions in WAS.

Keywords: Waste activated sludge; Photocatalytic pretreatment; Redox conversion; Anaerobic hydrogen production; Heavy metals

\section{Introduction}

Hydrogen is a promising alternative energy that produces high energy without greenhouse gases during the combustion process [1]. Hydrogen can be produced by both chemical and biological methods. Chemically, hydrogen can be produced by electrolysis and photocatalytic water splitting [2]. The latter is more energy-efficient than the former. Biologically, hydrogen can be generated by both photo-fermentation and dark fermentation [3] with the latter being more effective under present conditions. Some attempts have been tried to test hydrogen 
production from easily biodegradable organics rich in glucose and sucrose $[4,5]$. Recently, hydrogen production has also been explored on the wastes containing refractory materials such as cornstalk and waste activated sludge (WAS) $[6,7]$.

As for WAS, however, hydrolysis is the rate-limiting step in anaerobic digestion and its digestion inefficiency resulted from long hydraulic retention time (HRT) can be overcome under the condition of effective disintegration of microbial cells and hydrolysis of extracellular polymeric substances (EPS) in WAS [8]. Moreover, heavy metal ions $(\mathrm{Cr}, \mathrm{Pb}, \mathrm{Cu}$, $\mathrm{Zn}, \mathrm{Ni}$ and $\mathrm{Cd}$ ) at concentrations above critical values in WAS will be toxic to microorganisms (hydrogenogens and methanogens) in anaerobic digestion process and to the natural ecosystem after being discharged into the environment [9]. Furthermore, the WAS can be easily converted to an agricultural fertilizer, if the heavy metal ions are removed or reduced to a non-toxic state by pretreatment. In order to improve the hydrolysis process as well as increase hydrogen yield, remove heavy metal ions and shorten the retention time, various pretreatment methods have been tested including alkaline pretreatment [10], acidification [11], ultrasonic treatment [12], microwave irradiation [13], enzyme [14], photocatalytic pretreatment $[15,16]$ and thermal hydrolysis [17-19]. However, it should be mentioned that all of the above methods increase the cost of sludge treatment when energy consumption and environmental benefits being taken into consideration. Photocatalysis, as an energy-saving and environment-friendly method, has been tested and used on wastewater treatment. The catalyst $\left(\mathrm{TiO}_{2}\right)$ can generate reducing conduction band electrons $\left(\mathrm{e}_{\mathrm{cb}}{ }^{-}\right)$and oxidizing valence band holes $\left(\mathrm{h}_{\mathrm{vb}}{ }^{+}\right)$in sufficient quantity with UV-light irradiation. However, few reports can be found on the photocatalytic method as a promising pretreatment to improve hydrogen production from WAS via anaerobic digestion [16].

The objective of this research is to evaluate the effect of photocatalytic pretreatment on biohydrogen production from WAS and the photo-reduction capacity for heavy metal ions in 
WAS. For this purpose, the compositions of WAS and metabolites after anaerobic digestion were determined. In addition, the concentrations of soluble carbohydrate, protein and heavy metal ions $(\mathrm{Cu}, \mathrm{Zn}, \mathrm{Cr}, \mathrm{Ni}, \mathrm{Pb}, \mathrm{Cd})$ were also analyzed to disclose the changes of photo-oxidation capacity for organics and photo-reduction capacity for heavy metal ions in WAS after pretreatment.

\section{Materials and Methods}

\subsection{WAS, digested sludge and catalyst}

The WAS and digested sludge were collected from a sewage treatment plant in Shimodate, Ibaraki, Japan, then kept at $4^{\circ} \mathrm{C}$. The characteristics of the WAS were shown in Table 1.The ratio $(66.90 \%)$ of volatile solids (VS)/total solids (TS) indicates that the main components of the sludge were organic substances. The low ratio (9.60\%) of soluble chemical oxygen demand (SCOD)/total chemical oxygen demand (TCOD) demonstrates that most COD is insoluble. Digested sludge was used as seeding sludge in the thermophilic anaerobic hydrogen fermentation experiment. The $\mathrm{pH}$, TS, VS, TCOD and SCOD of the digested sludge were 7.1, $10.7 \mathrm{~g} / 1,7.3 \mathrm{~g} / 1,19.7 \mathrm{~g} / 1$ and $0.5 \mathrm{~g} / \mathrm{l}$, respectively. Before used as seed inoculums, the digested sludge was heat-treated in a hot air oven at $120^{\circ} \mathrm{C}$ for 30 minutes to inhibit methanogen [16]. The catalyst used in this study was a Degussa P-25 $\mathrm{TiO}_{2}$ slurry (Degussa AG, Germany).

\subsection{Pretreatment experiments}

Photocatalysis was used as sludge pretreatment method in this study. As reported in our 
previous study [16], the optimal pretreatment conditions were obtained as $\mathrm{TiO}_{2}$ dosage of 3 $\mathrm{g} / \mathrm{l}$, circulating speed of $350 \mathrm{ml} / \mathrm{min}$, UV-light intensity of $1.5 \mathrm{~mW} / \mathrm{cm}^{2}$, and duration of $6 \mathrm{~h}$ respectively in a circulating bed photocatalytic reactor. In this study, $180 \mathrm{ml}$ raw WAS and 3 $\mathrm{g} / 1 \mathrm{TiO}_{2}$ were mixed completely, and then treated in a circulating bed photocatalytic reactor. In order to test the effect of photocatalysis with $\mathrm{TiO}_{2}$ addition on WAS, UV-light pretreatment experiment (without $\mathrm{TiO}_{2}$ ) was also conducted under the identical conditions.

\subsection{Batch anaerobic digestion for bio-hydrogen production}

The experiment of bio-hydrogen production from WAS was conducted in $30 \mathrm{ml}$ serum bottles with a working volume of $25 \mathrm{ml}$ containing $18 \%(\mathrm{v} / \mathrm{v})$ of inoculum. The batch experiments were performed in duplicate under $55^{\circ} \mathrm{C}$ for 5 days, using photocatalysis pretreated WAS, UV-light pretreated WAS and raw WAS (control) as substrate, respectively. The initial $\mathrm{pH}$ of the substrate was adjusted to 5.7 with $1 \mathrm{~mol} / 1$ hydrochloric acid $(\mathrm{HCl})$. The serum bottles were closed with rubber stoppers and caps. After replacement of the headspace with nitrogen to create anaerobic condition, the serum bottles were put into a temperature-controlled water-bath $\left(55^{\circ} \mathrm{C}\right)$. The biogas production was measured every $12 \mathrm{~h}$ by water displacement method. The volatile fatty acids (VFAs) concentrations was determined every $12 \mathrm{~h}$ by HPLC. The fermentation medium was sampled at the initial and end of the hydrogen fermentation process for the measurement of $\mathrm{pH}$, TS, VS, TCOD, SCOD, ammonia nitrogen, soluble protein, and soluble carbohydrate concentrations.

\subsection{Analytical methods}

COD, TS, and VS were detected in accordance with standard methods [22], and pH was 
determined by a digital $\mathrm{pH}$ meter (Metter-Toledo Group). Liquid sample was centrifuged at $10,000 \mathrm{rpm}$ for 10 minutes and the supernatant was used to determine SCOD, carbohydrate and protein concentrations. The concentration of ammonium nitrogen was determined by an Ion meter (Ti 9001, Toyo Chemical Laboratories Co., Ltd.). Phenol sulfuric method [23] with glucose as standard was used to determine carbohydrate concentration. Lowry method [24] with bovine serum albumin as standard was used to measure soluble protein. The concentrations of heavy metal ions $(\mathrm{Cd}, \mathrm{Zn}, \mathrm{Pb}, \mathrm{Gr}, \mathrm{Cu}, \mathrm{Ni})$ were analyzed by inductively coupled plasma mass spectrometry (ICP-MS: 2000 spectrometer Jobin-Yvon, Longjumeau, France). The liquid samples were centrifuged at 10,000 rpm for 10 minutes, and filtered through a $0.22 \mu \mathrm{m}$ diameter filtration membrane before injection to ICP-MS. Biogas compositions including hydrogen, methane and carbon dioxide were determined by gas chromatography (GC-8A, SHIMAZU, JAPAN). VFAs including acetic (Ac), propionic (Pr), butyric $(\mathrm{Bu})$ and Valeric (Va) acids were measured by a high performance liquid chromatography (HPLC, EcomLCP4100 Pump, LCD 2083 Detector, ECOM, Czech Rep.) with an ultraviolet (210 nm) detector (UV1000, Thermo Electron) and a Fast Acid Analysis column (Bio-Rad Lab.) using $0.005 \mathrm{M}$ sulfuric acid as mobile phase at $1 \mathrm{ml} / \mathrm{min}$. The liquid samples were centrifuged at 10,000 rpm for 10 minutes, and filtered through $0.45 \mathrm{~mm}$ cellulose acetate membrane before injection to HPLC.

\section{Results and discussion}

\subsection{Effect of photocatalytic pretreatment on WAS}

As shown in Table 1, after photocatalytic pretreatment, the concentration of SCOD increased from 1752 to $3620 \mathrm{mg} / \mathrm{l}$, and the soluble protein and carbohydrate concentrations 
also increased approximately by $50 \%$ and $80 \%$, respectively compared with the raw WAS. In addition, the decrease of TCOD and the increase of SCOD confirm the disruption of the floc structure of WAS and the release of extracellular and intracellular biopolymers from activated sludge flocs into the soluble phase $[25,26]$. The large increase of soluble protein and carbohydrate concentration can be attributed to the release of extracellular polymeric substance (EPS) and cellular substances into the aqueous phase after photocatalytic pretreatment [27]. The increase of $\mathrm{NH}_{4}{ }^{+}-\mathrm{N}$ concentration in photocatalysis pretreated WAS was probably contributed by the degradation of some nitrogenous organics such as proteins and nucleic acid [12], which leaded to the $\mathrm{pH}$ increase of WAS after pretreatment. The results also indicate that UV-light had much less contribution to the disintegration of WAS and the release of soluble organics which was mainly brought about by the photocatalytic pretreatment. Restated, the changes of organics in WAS are owing to the oxidization of $\mathrm{TiO}_{2}$ photocatalysis. When the refractory organics in WAS capture the valence band hole $\left(\mathrm{h}^{+}\right)$, they will be oxidized and release small molecule organics. Therefore, photocatalytic pretreatment can enhance the solubilization of sludge and eventually improve the bio-degradability of WAS $[16,28]$.

\subsection{Effect of photocatalytic pretreatment on the removal of heavy metal ions}

Oxidation by photo-generated holes takes place concurrently with reduction by the photo-generated electrons in a heterogeneous photocatalytic process [9]. In the photocatalysis process of WAS, the organic pollutants in WAS can capture the valence band hole and be oxidized, and heavy metal ions in WAS may trap the conduction band electrons and then be reduced.

The concentration changes in six heavy metal ions in the liquid phase of WAS are shown in Fig.1. The results indicate that the removal rate is different with respect to different metal 
ions. $\mathrm{Cr}$ (VI) can be removed with the highest rate of $97.0 \%$; the reason is probably that $\mathrm{Cr}$ (VI) was first photo-reduced to $\mathrm{Cr}$ (III) which then was removed by precipitation as $\mathrm{Cr}(\mathrm{OH})_{3}$ $[20,29]$. The removals of $\mathrm{Cu}$ (II) $(92.0 \%)$ and $\mathrm{Pb}$ (II) (91.6\%) follow, possibly due to that both heavy metal ions have more than $+0.3 \mathrm{~V}$ of half-reaction standard reduction potentials and can be photo-reduced when using $\mathrm{TiO}_{2}$ as catalyst $[20,21]$. Generally, $\mathrm{Zn}$ (II), Cd (II) and $\mathrm{Ni}$ (II) can’t be directly photo-reduced because their reduction potentials are more negative than those of photo-generated electrons [21]. However, WAS usually contains several organic hole scavengers (such as amino and carboxyl groups) which can enhance the removals of $\mathrm{Zn}$ (II), $\mathrm{Cd}$ (II) and $\mathrm{Ni}$ (II) [20, 30]. The removal rates of Cd (II), Ni (II) and $\mathrm{Zn}$ (II) were 83.7\%, $82.3 \%$ and $81.0 \%$, respectively in this study.

The results suggest that sufficient mixing or stirring could slightly $(4.8 \%-10.6 \%)$ enhance the removal of heavy metal ions (Fig. 1). This observation might be brought about by the surface complexation of heavy metals with negatively charged polymers, ions exchange, precipitation, etc. during the stirring $[17,20]$. UV-light pretreatment also has some slight improvement effect (24.2\%-30.1\%) on the removal of heavy metal ions. Obviously, photocatalytic pretreatment can significantly $(81.0 \%-97.0 \%)$ enhance the removal of heavy metal ions probably by photo-reduction $[9,31]$ and/or by surface complexation with more soluble negatively charged functional groups [17] produced during the photocatalytic pretreatment process. The reason might be that heavy metal ions as electron acceptors could be photo-reduced, and the simultaneous photo-oxidation of organic molecules might accelerate this photo-reduction by offering electron donors [31], and vice versa. The oxidation-reduction synergistic reaction can add advantageous effect to sludge treatment under high concentration of heavy metal ions, which probably has improvement effect on hydrogen production. 


\subsection{Effect of photocatalytic pretreatment on hydrogen production}

Fig. 2a indicates the hydrogen production from raw WAS, UV-light pretreated WAS and photocatalysis pretreated WAS. The cumulative hydrogen production increased rapidly during the first $12 \mathrm{~h}$ till day 3 with the increasing trend leveling off after 3.5 day's fermentation. The three kinds of sludge did not produce any more hydrogen after day 5 with the order of cumulative hydrogen yields as follows: photocatalysis pretreated WAS > UV-light pretreated WAS > raw WAS, which was 211.0, 111.0 and $93.0 \mathrm{ml} / \mathrm{l}$-sludge, respectively. That means that photocatalytic pretreatment could remarkably promote hydrogen production from sludge. Meanwhile, no methane was detected from the photocatalysis pretreated WAS (Fig. 2b). Conversely, methane was produced from the anaerobic digestion of UV-light pretreated WAS and the raw WAS from day 2 on, and their cumulative methane productions were 19.9 and $60.3 \mathrm{ml} / \mathrm{l}$-sludge, respectively. The results indicate that utilizing the photocatalytic pretreated WAS as substrate is most effective for anaerobic hydrogen production in comparison with the raw WAS and UV-light pretreated WAS. By comparison with other pretreatment methods, hydrogen production from photocatalysis pretreated WAS via thermophilic fermentation $\left(55^{\circ} \mathrm{C}\right)$ is more effective with the hydrogen yield of $211.0 \mathrm{ml} / \mathrm{l}$-sludge. In our previous study, the hydrogen yield was 53.2 $\mathrm{ml} /$-sludge [16] from photocatalysis pretreated WAS via mesophilic fermentation $\left(35^{\circ} \mathrm{C}\right)$. Guo et al. [33] achieved $43 \mathrm{ml} / \mathrm{l}$-sludge of hydrogen from ultrasonic pretreated WAS via mesophilic fermentation $\left(35^{\circ} \mathrm{C}\right)$. Restated, photocatalytic technology could be a promising pretreatment for the degradation of refractory organics for biohydrogen production.

\subsection{Effect of pretreatment on metabolites and $\mathrm{pH}$ value}


The gas phase analysis showed that only $\mathrm{H}_{2}$ and $\mathrm{CO}_{2}$ were detected in the biogas from the photocatalysis pretreated WAS during the process of hydrogen production. A similar result was also reported by Guo et al. [33] who treated waste sludge by sterilization, microwave and ultrasonication. Conversely, in the controls (raw WAS), $\mathrm{CH}_{4}$ was not only detected but also increased with time in the later stage of hydrogen production.

Liquid product analysis showed that after fermentation the metabolites were mainly acetate, propionate and butyrate. The major difference in VFAs among the three kinds of sludge lay in the changes of Ac acid concentration. The cumulative concentrations were 528, 643 and 1020 $\mathrm{mg} / \mathrm{l}$ for Ac, 365,326 and $296 \mathrm{mg} / \mathrm{l}$ for Pr, 420, 451 and $620 \mathrm{mg} / \mathrm{l}$ for Bu acids in the raw, UV pretreated and photocatalysis pretreated WAS, respectively. During the entire fermentation process, $\mathrm{Pr}$ and $\mathrm{Bu}$ acids concentration increased continuously in the three sludge reactors, while the Ac acid concentration changed differently in the three reactors. Ac acid increased continuously in the photocatalysis pretreated WAS (Fig. 3c), but first increased then decreased from day 3 in the UV-light pretreated WAS (Fig. 3b) and raw WAS (Fig. 3a) reactors. Moreover, the decrease rate in the raw WAS reactor was higher than that in the UV-light pretreated WAS reactor. This result is in accordance with the change of methane in these two reactors shown in Fig. 2b. This phenomenon implies that Ac acid might be consumed for methane production [34]. The fact that Ac acid concentration was the highest among the three major VFAs, indicates that biohydrogen production from WAS is still an Ac acid type fermentation [35], i.e. the photocatalysis pretreatment does not change the fermentation type of WAS.

Although the concentrations of VFAs increased disproportionately, the $\mathrm{pH}$ values did not decrease but increased from the same initial value of 5.7 to 5.9, 5.9 and 6.1, respectively (Fig. 4). This observation could be largely attributed to the increase in $\mathrm{NH}_{4}{ }^{+}-\mathrm{N}$ concentration in three sludge reactors (Fig. 4). 


\subsection{Comparison with other pretreatments}

WAS pretreatment has positive effects on the solubilization of organic materials [36]. However, not all of these pretreated WAS are appropriate for anaerobic hydrogen production. The advantages and disadvantages of these pretreatments are listed in Table 2. Acid and alkaline pretreatment without heating have less effect on hydrogen production and might cause secondary pollution to the environment due to chemical addition $[7,10,11,36]$. Microwave and heating can efficiently enhance hydrogen production but consume large amount of energy at the same time $[1,17,33,36]$. Guo et al. [33] noted that ultrasonic pretreatment would inhibit hydrogen production due to the production of some inhibitors and extraction of heavy metal ions during the pretreatment process. Wang et al. [5] reported that enzyme pretreatment was an expensive method and had some problems related to adsorption and desorption from substrate surfaces. Although there are some problems like low efficiency of supported catalyst resulting in the requirement of some special photocatalytic reactor, photocatalysis has been proved to be a more low-cost and eco-friendly pretreatment method than others. During this process, organic pollutants can be photo-oxidized with heavy metal ions being photo-reduced and eventually hydrogen production being improved. In addition, this process can make use of solar energy directly, and the catalyst is nontoxic and sometimes reusable. For example, after the photocatalytic pretreatment of WAS, the mixture of suspended $\mathrm{TiO}_{2}$ and WAS can be used for synthesis of adsorbent [29]. Therefore, photocatalysis is expected to be widely applied in the pretreatment of WAS in the near future.

\section{Conclusions}


Photocatalytic pretreatment of WAS is an alternative method to promote the release of soluble organics and the uptake of heavy metal ions. In the meantime, the increase of soluble organics, especially soluble carbohydrate and soluble protein, and the decrease of heavy metal ions in the liquid phase further enhanced the hydrogen production from WAS by dark anaerobic digestion. The maximum cumulative hydrogen yields of 211.0, 111.0 and 93.0 $\mathrm{ml} /$-sludge were achieved from photocatalysis pretreated WAS, UV-light pretreated WAS and raw WAS, respectively. Moreover, $\mathrm{CH}_{4}$ was not detected in the gas phase during hydrogen production from the photocatalysis pretreated WAS. In contrast, $\mathrm{CH}_{4}$ was not only present but also increased over time during the later stages of hydrogen production from raw sludge. The main liquid metabolite was acetic acid, suggesting that dark anaerobic hydrogen fermentation of photocatalysis pretreated WAS was still an acetic acid type fermentation.

\section{Acknowledgements}

We are grateful to Ms. Jie Chen (Graduate School of Life and Environmental Science, the University of Tsukuba) for her help with part of the experiments. We also appreciate the efforts of Ms. Huiling Zhang (Chinese Language \& Culture College, the Beijing Normal University) for providing language help and writing assistance.

\section{References}

[1] Thungklin P, Reungsang A, Sittijunda S. Hydrogen production from sludge of poultry slaughterhouse wastewater treatment plant pretreated with microwave. Int J Hydrogen Energy 2011;36: 8751-7.

[2] Yan W, Zheng CL, Liu YL, Guo LJ. A novel dual-bed photocatalytic water splitting system 
for hydrogen production. Int J Hydrogen Energy 2011; 36: 7405-9.

[3] Argun H, Kargi F. Bio-hydrogen production by different operational modes of dark and photo-fermentation: An overview. Int J Hydrogen Energy 2011; 36: 7443-59.

[4] Li Z, Wang H, Tang $\mathrm{Z}$ et al. Effects of $\mathrm{pH}$ value and substrate concentration on hydrogen production from the anaerobic fermentation of glucose. Int J Hydrogen Energy 2008; 33: $7413-8$

[5] Wang H, Wang J, Fang Z et al. Enhanced bio-hydrogen production by anaerobic fermentation of apple pomace with enzyme hydrolysis. Int J Hydrogen Energy 2010; 35 : 8303-9.

[6] Pan C-M, Ma H-C, Fan Y-T, Hou H-W. Bioaugmented cellulosic hydrogen production from cornstalk by integrating dilute acid-enzyme hydrolysis and dark fermentation. Int $\mathrm{J}$ Hydrogen Energy 2011; 36: 4852-62.

[7] Devlin DC, Esteves SRR, Dinsdale RM et al. The effect of acid pretreatment on the anaerobic digestion and dewatering of waste activated sludge. Bioresour Technol 2011; 102(5): 4076-82.

[8] Appels L, Assche AV, Willems K et al., Peracetic acid oxidation as an alternative pre-treatment for the anaerobic digestion of waste activated sludge. Bioresour Technol 2011; 102: 4124-30.

[9] Jaesang L, Jungwon $\mathrm{K}$, and Wonyong $\mathrm{C}$. $\mathrm{TiO}_{2}$ Photocatalysis for the Redox Conversion of Aquatic Pollutants, in Aquatic Redox Chemistry 2011, J Am Chem Soc. pp. 199-22.

[10] Lin Y, Wang D, Wu S, Wang C. Alkali pretreatment enhances biogas production in the anaerobic digestion of pulp and paper sludge. J Hazard Mater 2009; 170: 366-73.

[11] Khamtib S, Plangklang P, Reungsang A. Optimization of fermentative hydrogen production from hydrolysate of microwave assisted sulfuric acid pretreated oil palm trunk by hot spring enriched culture. Int J Hydrogen Energy 2011; 36: 14204-16. 
[12] Pilli S, Bhunia P, Yan S et al. Ultrasonic pretreatment of sludge: A review. Ultrason Sonochem 2011; 18: 1-18.

[13] Sólyom K, Mato RB, Pérez-Elvira SI, Cocero MJ. The influence of the energy absorbed from microwave pretreatment on biogas production from secondary wastewater sludge. Bioresour Technol 2011; 102: 10849-54.

[14] Yang Q, Luo K, Li X-m et al. Enhanced efficiency of biological excess sludge hydrolysis under anaerobic digestion by additional enzymes. Bioresour Technol 2010; 101: 2924-30.

[15] da Rocha ORS, Dantas RF, Duarte MMMB et al. Oil sludge treatment by photocatalysis applying black and white light. Chem Eng J 2010; 157: 80-5.

[16] Liu C, Yang Y, Wang Q, et al. Photocatalytic degradation of waste activated sludge using a circulating bed photocatalytic reactor for improving biohydrogen production. Bioresour Technol 2012; 125:30-36.

[17] Laurent J, Casellas M, Carrère H, Dagot C. Effects of thermal hydrolysis on activated sludge solubilization, surface properties and heavy metals biosorption. Chem Eng J 2011; 166: 841-9.

[18] Wilson CA, Novak JT. Hydrolysis of macromolecular components of primary and secondary wastewater sludge by thermal hydrolytic pretreatment. Water Res 2009; 43: 4489-98.

[19]Uma Rani R, Adish Kumar S, Kaliappan S et al. Low temperature thermo-chemical pretreatment of dairy waste activated sludge for anaerobic digestion process. Bioresour Technol 2012; 103: 415-24.

[20] Chen D and Ray A K. Removal of toxic metal ions from wastewater by semiconductor photocatalysis. Chem Eng Sci 2001; 56(4): 1561-1570.

[21] Chenthamarakshan CR, Rajeshwar K. Photocatalytic reduction of divalent zinc and cadmium ions in aqueous $\mathrm{TiO}_{2}$ suspensions: an interfacial induced adsorption-reduction 
pathway mediated by formate ions. Electrochem Commun 2000; 2(7): 527-530.

[22] Clesceri L S, Greenberg AE, and Trussel R R (Ed.). Standard methods for the examination of water and wastewater, 17th edition. American Public Health Association, Washington, 1989, pp.1644.

[23] Mecozzi M. Estimation of total carbohydrate amount in environmental samples by the phenol-sulphuric acid method assisted by multivariate calibration. Chemometr Intell lab 2005; 79: 84-90.

[24] Frølund B, Palmgren R, Keiding K, Nielsen PH. Extraction of extracellular polymers from activated sludge using a cation exchange resin. Water Res 1996; 30: 1749-58.

[25] Vimonses V, Jin B, Chow CWK, Saint C. An adsorption-photocatalysis hybrid process using multi-functional-nanoporous materials for wastewater reclamation. Water Res 2010; 44: 5385-97.

[26] Jamil TS, Ghaly MY, El-Seesy IE et al. A comparative study among different photochemical oxidation processes to enhance the biodegradability of paper mill wastewater. J Hazard Mater 2011; 185: 353-8.

[27] Yu Q, Lei H, Li Z, Li H, Chen K, Zhang X, Liang R. Physical and chemical properties of waste-activated sludge after microwave treatment. Water Res 2010; 44, 2841-2849.

[28] Val del Río A, Morales N, Isanta E et al. Thermal pre-treatment of aerobic granular sludge: Impact on anaerobic biodegradability. Water Res 2011; 45: 6011-20.

[29] Barakat MA. New trends in removing heavy metals from industrial wastewater. Arab J Chem 2011. 4(4): 361-77.

[30]Kabra K, Chaudhary R, Sawhney RL. Effect of $\mathrm{pH}$ on solar photocatalytic reduction and deposition of $\mathrm{Cu}(\mathrm{II}), \mathrm{Ni}(\mathrm{II}), \mathrm{Pb}(\mathrm{II})$ and $\mathrm{Zn}(\mathrm{II})$ : Speciation modeling and reaction kinetics. J Hazard Mater 2007; 149: 680-5.

[31] Vinu R and Madras G. Kinetics of Simultaneous Photocatalytic Degradation of Phenolic 
Compounds and Reduction of Metal Ions with Nano-TiO 2 . Environ Sci Technol 2007; 42(3): 913-19.

[32] Kyung H, Lee J, and Choi W. Simultaneous and Synergistic Conversion of Dyes and Heavy Metal Ions in Aqueous $\mathrm{TiO}_{2}$ Suspensions under Visible-Light Illumination. Environ Sci Technol 2005; 39(7): 2376-82.

[33] Guo L, Li X-M, Bo X et al. Impacts of sterilization, microwave and ultrasonication pretreatment on hydrogen producing using waste sludge. Bioresour Technol 2008; 99: $3651-8$

[34] Ting CH, Lee DJ. Production of hydrogen and methane from wastewater sludge using anaerobic fermentation. Int J Hydrogen Energy 2007; 32: 677-82.

[35] Cui M, Shen J. Effects of acid and alkaline pretreatments on the biohydrogen production from grass by anaerobic dark fermentation. Int J Hydrogen Energy 2012; 37: 1120-4.

[36] Carrère H, Dumas C, Battimelli A et al. Pretreatment methods to improve sludge anaerobic degradability: A review. J Hazard Mater 2010; 183: 1-15. 
Table 1 The characteristics of waste activated sludge (WAS) before and after pretreatment by UV-light and photocatalysis

\begin{tabular}{llll}
\hline Items & Raw & $\begin{array}{l}\text { UV-light } \\
\text { pretreated } \\
\text { WAS }\end{array}$ & $\begin{array}{l}\text { Whotocatalysis } \\
\text { pretreated } \\
\text { WAS }\end{array}$ \\
\hline TCOD (total chemical oxygen demand, mg/l) & 18249 & 17981 & 17210 \\
SCOD (soluble chemical oxygen demand, mg/l) & 1752 & 1893 & 3620 \\
TS (total solids, mg/l) & 7483 & 7302 & 6870 \\
VS (volatile solids, mg/l) & 5006 & 5119 & 5980 \\
Soluble protein (mg/l) & 1293 & 1386 & 1946 \\
Soluble carbohydrate (mg/l) & 486 & 504 & 879 \\
$\mathrm{NH}_{4}^{+}-\mathrm{N}(\mathrm{mg} / \mathrm{l})$ & 106 & 130 & 320 \\
$\mathrm{pH}$ & 6.7 & 7.3 & 7.6 \\
\hline
\end{tabular}


Table 2 Main advantages and disadvantages of various pretreatment methods for waste activated sludge (WAS)

\begin{tabular}{|c|c|c|c|c|}
\hline $\begin{array}{l}\text { Treatment } \\
\text { method }\end{array}$ & $\begin{array}{l}\text { Experimental } \\
\text { conditions }\end{array}$ & Advantages & Disadvantages & $\begin{array}{l}\text { Refer } \\
\text { ences }\end{array}$ \\
\hline Heating & $\begin{array}{l}121-180^{\circ} \mathrm{C}, \\
20 \mathrm{~min}-60 \mathrm{~min}, \\
600-2500 \mathrm{kbar}\end{array}$ & $\begin{array}{l}\text { Improve the solids } \\
\text { hydrolysis rate, reduce } \\
\text { sludge volume, no } \\
\text { chemical addition, adsorb } \\
\text { toxic metals, increase } \\
\text { hydrogen yield. }\end{array}$ & $\begin{array}{l}\text { Increase final effluent } \\
\text { color and ammonia } \\
\text { inhibition, high energy } \\
\text { consumption. }\end{array}$ & $\begin{array}{l}{[17,} \\
33 \\
36]\end{array}$ \\
\hline Acid & $\begin{array}{l}\text { Adjust solution } \\
\text { to } \mathrm{pH}=2 \text { using } \\
37 \% \mathrm{HCl}, 24 \mathrm{~h} \text {, } \\
\text { then to } \mathrm{pH}=7 \\
\text { using } \\
\mathrm{NaOH} / \mathrm{Ca}(\mathrm{OH})_{2}\end{array}$ & $\begin{array}{l}\text { Low-cost, easy to } \\
\text { operate, high } \\
\text { metal-binding capacities. }\end{array}$ & $\begin{array}{l}\text { Low selectivity, produce } \\
\text { waste products and } \\
\text { inhibitors, time } \\
\text { consuming. }\end{array}$ & $\begin{array}{l}{[7,} \\
11]\end{array}$ \\
\hline Alkaline & $\begin{array}{l}8 \mathrm{~g} \mathrm{NaOH} / 100 \mathrm{~g} \\
\text { TS-sludge, } \\
20 \mathrm{~min}-60 \mathrm{~min}\end{array}$ & $\begin{array}{l}\text { Low-cost, easy to } \\
\text { operate, high } \\
\text { metal-binding capacities, } \\
\text { increase hydrogen yield. }\end{array}$ & $\begin{array}{l}\text { Low selectivity, produce } \\
\text { waste products, time } \\
\text { consuming, higher } \\
\text { concentration inhibition. }\end{array}$ & $\begin{array}{l}{[10,} \\
36]\end{array}$ \\
\hline $\begin{array}{l}\text { Microwav } \\
\text { e }\end{array}$ & $\begin{array}{l}560 \mathrm{w} \times 2 \mathrm{~min} \\
850 \mathrm{~W} \times 3 \mathrm{~min}\end{array}$ & $\begin{array}{l}\text { Significantly reduce } \\
\text { sludge volume and } \\
\text { processing time, ease of } \\
\text { control, compactness, no } \\
\text { chemical addition, no } \\
\text { harmful by-products, } \\
\text { increase hydrogen yield. }\end{array}$ & $\begin{array}{l}\text { Destruct microorganisms } \\
\text { non-selectively, higher } \\
\text { energy consumption, } \\
\text { extract heavy metal ions } \\
\text { from sludge. }\end{array}$ & $\begin{array}{l}{[1,} \\
33]\end{array}$ \\
\hline Ultrasonic & $\begin{array}{l}2 \mathrm{w} / \mathrm{ml} \times 5 \mathrm{~min} \\
5000 \mathrm{~kJ} / \mathrm{kg} \\
\mathrm{TSS} \times 5 \mathrm{~min}\end{array}$ & $\begin{array}{l}\text { Effectively improve } \\
\text { organics solubilization } \\
\text { and sludge disintegration, } \\
\text { less retention time, } \\
\text { reduce sludge volume, } \\
\text { less harmful by-products. }\end{array}$ & $\begin{array}{l}\text { Fail to reduce VS, } \\
\text { frequently replace the } \\
\text { ultrasound probes, } \\
\text { extract heavy metal ions } \\
\text { from sludge, reduce } \\
\text { hydrogen yield }\end{array}$ & $\begin{array}{l}{[18,33} \\
]\end{array}$ \\
\hline Enzyme & $\begin{array}{l}0.6 \%(\mathrm{w} / \mathrm{w}, \\
\text { enzyme/TS-slud } \\
\text { ge }), 40-50^{\circ} \mathrm{C}, 4 \mathrm{~h}\end{array}$ & $\begin{array}{l}\text { Easy to control, no } \\
\text { harmful by-products; } \\
\text { enhance solid reduction, } \\
\text { increase hydrogen yield. }\end{array}$ & $\begin{array}{l}\text { Limitation of accessible } \\
\text { surface area and enzyme } \\
\text { adsorption, pretreatment } \\
\text { needed to remove lignin } \\
\text { and hemicellulose. }\end{array}$ & $\begin{array}{l}{[5,14,} \\
]\end{array}$ \\
\hline $\begin{array}{l}\text { Photocatal } \\
\text { ysis }\end{array}$ & $\begin{array}{l}20 \mathrm{~W} \text { lamp, } \mathrm{TiO}_{2} \\
\text { of } 20 \mathrm{mg} / 1 \text {, and } \\
96 \mathrm{~h} \text {; } \\
15 \mathrm{~W} \text { lamp, } \\
\mathrm{TiO}_{2} \text { of } 3 \mathrm{~g} / 1, \\
\text { and } 6 \mathrm{~h}\end{array}$ & $\begin{array}{l}\text { Remove heavy metals } \\
\text { and organic pollutant } \\
\text { simultaneously, no } \\
\text { harmful by-products, } \\
\text { increase hydrogen yield, } \\
\text { energy-saving and } \\
\text { environmentally-friendly. }\end{array}$ & $\begin{array}{l}\text { Time consuming, low } \\
\text { efficiency of supported } \\
\text { photocatalyst. }\end{array}$ & $\begin{array}{l}{[9,16,} \\
20]\end{array}$ \\
\hline
\end{tabular}


Figure captions

Fig.1. Concentration changes of heavy metal ions in control (raw WAS), Aeration WAS (stirring by magnetic stirrers, $6 \mathrm{~h}$ ), UV-light pretreated WAS, photocatalysis pretreated WAS Fig.2. Effect of photocatalytic pretreatment on (a) hydrogen production; (b) methane production

Fig.3. VFA variations during hydrogen fermentation (a) in raw WAS; (b) UV-light pretreated WAS; (c) photocatalysis pretreated WAS

Fig.4. Changes of $\mathrm{pH}$ and $\mathrm{NH}_{4}{ }^{+}-\mathrm{N}$ before and after hydrogen fermentation in three kinds WAS 


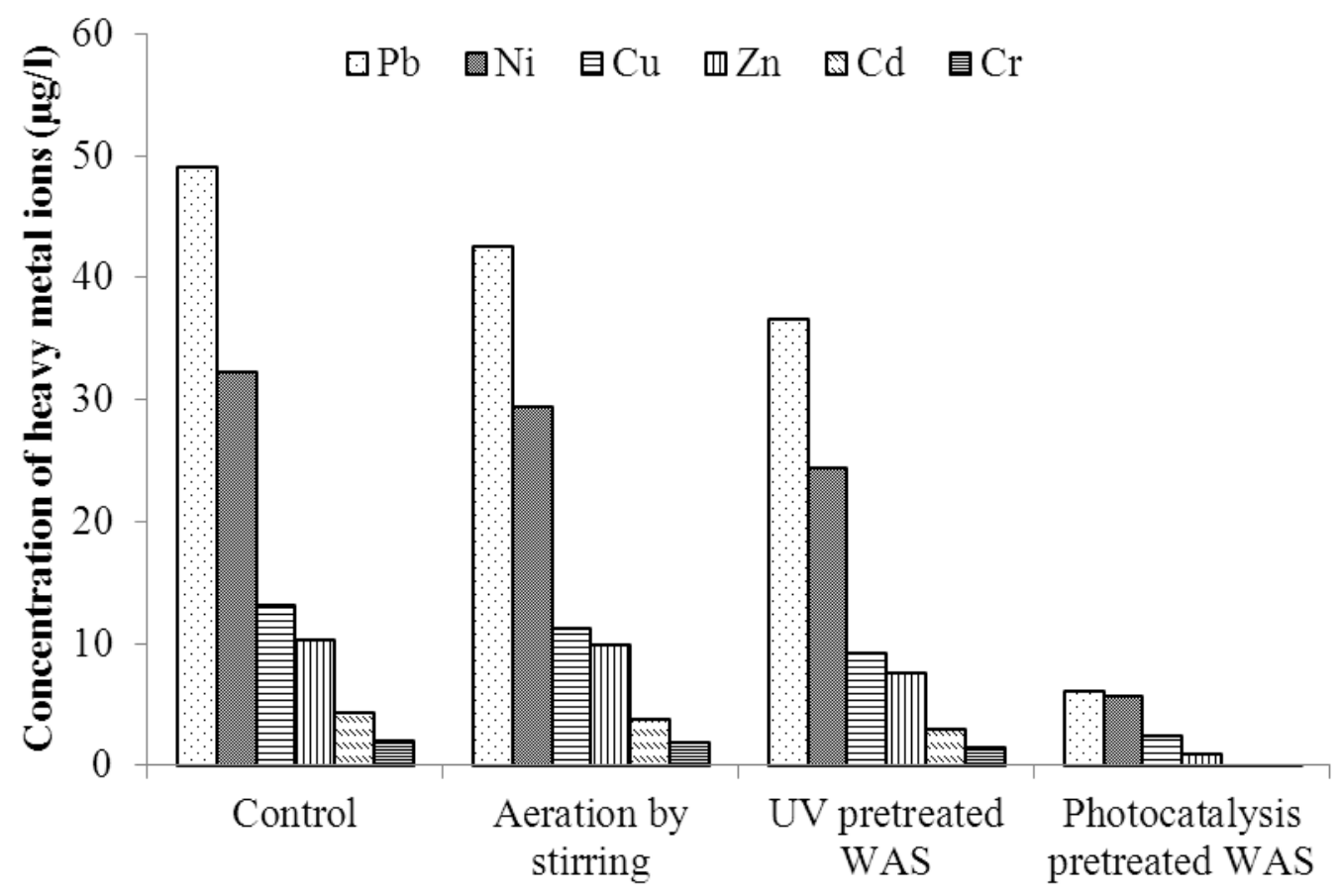

Fig.1. Liu et al. 

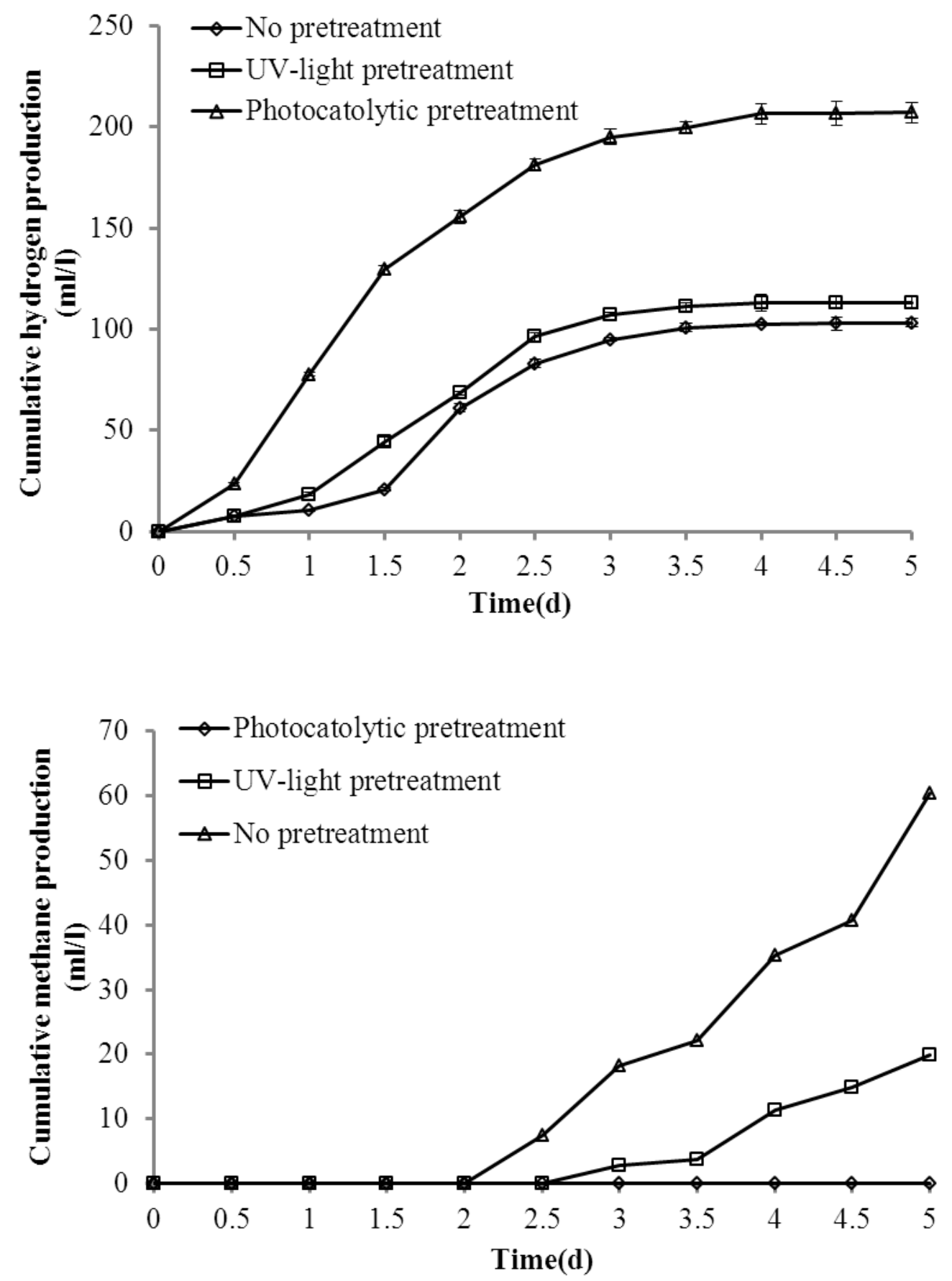

Fig.2. Liu et al. 
(a)

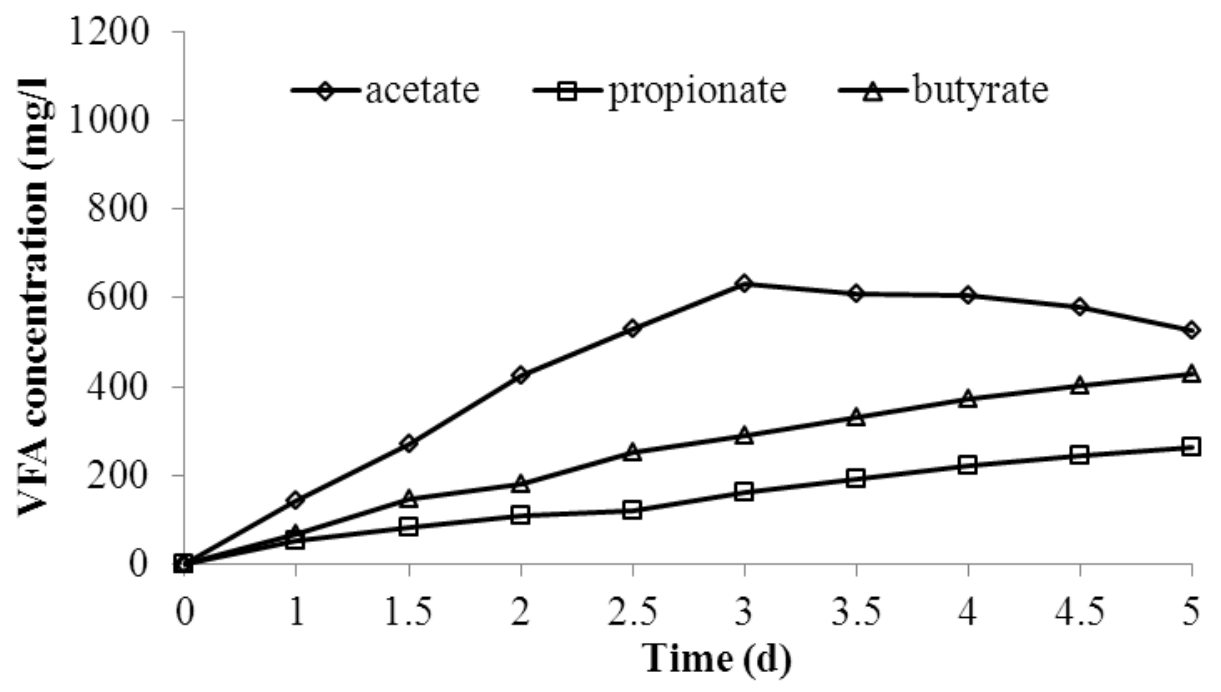

(b)
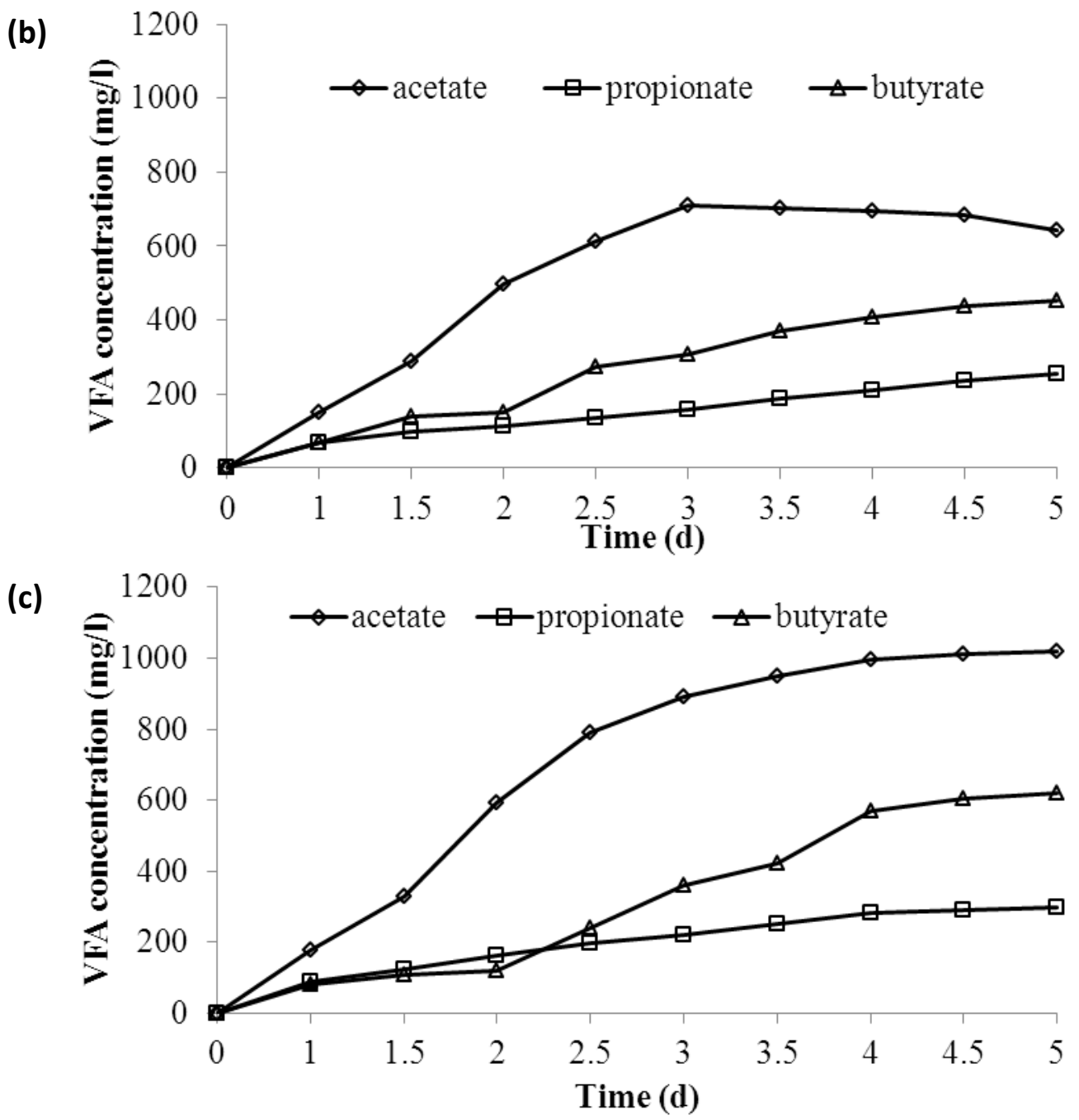

Fig.3. Liu et al. 


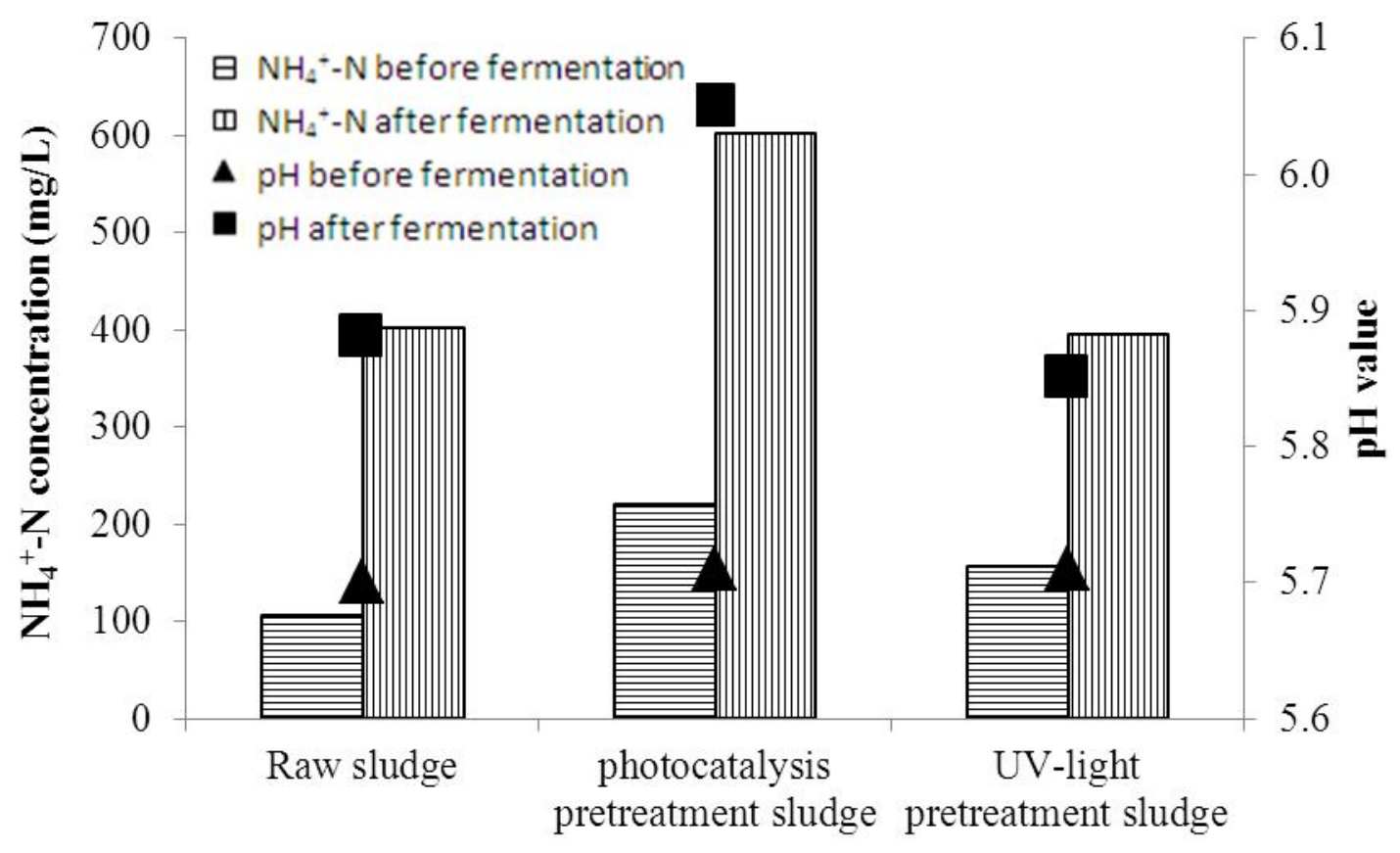

Fig.4. Liu et al. 